\section{Immigrant Youth Mental Health Promotion in Transnationalizing Societies}

\section{Introduction}

As global migration trends continue into the $21^{\text {st }}$ Century, the nursing profession must respond rapidly through research and practice in addressing the needs of transnationalizing societies. The changing demographic mosaic of multicultural and multiracial cities provides unique opportunities for nurses in the North and South to learn from each other. This paper is an attempt to contribute to the field of international nursing scholarship and partnership in mental health promotion. Through sharing lessons learned in mental health promotion research with youth in multicultural and immigrant-receiving settings in Canada, it is hoped that cross-learning between nursing scholars and practitioners in Brazil and Canada can be fostered.

\section{Immigration patterns in Brazil and Canada}

Due to their different migration histories, Brazil's ethnoracial pluralistic societies have a longer-standing history compared to Canada. Although the migration histories and trends of newcomers to Brazil and Canada are distinct, immigration trends have resulted in societies with increasing diversities of peoples from different nations, races, and cultures. Immigration into Brazil occurred mainly during the $19^{\text {th }}$ Century and early $20^{\text {th }}$ Century. Before this period, the country was composed basically of aboriginal peoples, Portuguese colonizers, and black slaves. Between 1882 and 1934 a total of 4.5 million immigrated to Brazil(1). Countries of origin included those from Europe, the Middle East, and Asia. With decreases in immigration rates from the 1930s onwards, Japanese immigrants were the only immigrant group that continued to arrive in large numbers in the $1930 \mathrm{~s}^{(1)}$. As the country with the largest Japanese immigrant population, Brazil has significant numbers of second generation (Nisei) and third generation (Sansei) descendants of immigrant Japanese ${ }^{(2)}$.

In Canada, the source countries of immigrants have changed over the last decades. Less immigrants are from the traditional source countries and more are from recent source origins of immigration to Canada ${ }^{(3)}$. The United Kingdom and Italy are examples of traditional source countries. Among the more recent sources countries, Asian origins are predominant among those who immigrated in the 1980s and 1990s ${ }^{(4)}$. Immigrant children and youth comprise a significant number of newcomers to Canada. For example, between 1996 and 1998, approximately 230,000 immigrant children and youth arrived in Canada ${ }^{(5)}$. Therefore, as immigration policies continue to attract new immigrants into Canada, it is necessary for the nursing profession in Canada to consider how to best meet the health promotion needs of its immigrant youth.

\section{Youth and mental health promotion}

The period of adolescence has long been recognized as paramount in identity formation and psychosocial development. From a mental health perspective, in the post-industrial context of North America, the period entails its unique psychosocial challenges and resiliencies. Among immigrant youth, because of their unique migratory and resettlement experiences in a new country of residence, this period in development is coupled with distinct post-migration circumstances compared to mainstream youth.

A mental health promotion perspective recognizes the competencies and challenges of individuals within the context of their everyday lives and available systems resources ${ }^{(6,7)}$. Thus in nursing research and practice with youth, in addition to providing a systems-based understanding of youth's vulnerabilities, a mental health promotion perspective allows for an understanding of their strengths. A positive view of youth may help shift the conception of adolescence beyond what Lamb ${ }^{(8)}$ considered to be stereotyped ideas of victims and victimization that hold sway in developmental psychology, so that scholars could focus on the nature of successful development and the positive psychology of youth ${ }^{(9)}$. The learning gained would contribute to the positive mental health movement, which focuses on enhancing the positive aspects of daily functioning through efforts directed from the individual to the community levels ${ }^{(10)}$.

In our research with immigrant youth, we have applied a mental health promotion perspective alongside with participatory action research approaches ${ }^{(11,12)}$. In these community-based studies, we have interpreted the findings in light of the youth's competencies and available systems resources (or barriers to) in Canada, the resettlement society. For example, in our study of newcomer female in English as Second Language Classes ${ }^{(11)}$, we discussed our findings in terms of individual outcomes (such as self-esteem and self-concept) as well as recognizing the importance of relationships (parents and peers) on the youth. We considered the significant language barriers faced by the youth and the barriers by their parents due to underemployment or experiences of discrimination. In line with a mental health promotion approach, the 15 policy recommendations emerging from the study were not limited to the health care system. The recommendations addressed the following systems: education, health and social services, and resettlement services ${ }^{(11)}$.

\section{Conclusion}

A mental health promotion perspective has particular relevance in nursing research, policy, and practice in transnationalizing societies. In this paper we have considered the perspective in relation to work with immigrant youth in Canada. We argue that a mental health promotion approach pays heed to the intersectionalities of youth's individual strengths and vulnerabilities in connection with systemic support systems or barriers. In our work we have considered the intersectionality of gender, life stage, cultural, migrant and racialized status on mental health promotion in multicultural settings ${ }^{(13)}$. However, we posit that both a mental health promotion, and the increasingly popular concept of intersectionalities of influence ${ }^{(14)}$, can have relevance to transnationalizing societies elsewhere. We believe that the approach creates new opportunities for communitybased mental health nursing in diverse societies and allows for mutual learning across North-South and East-West borders. 


\section{Acknowledgement}

I would like to thank Dr. Denise Gastaldo (Faculty of Nursing, University of Toronto) for her valuable feedback on an earlier version of this paper.

\section{References}

1. Fausto B. Immigration, Brasília (DF): MRE; 2004. Available from URL: http://www.mre.gov.br/cdbrasil/itamaraty/web/ingles/consnac/ imigra/apresent/index.htm. Accessed at: 2004 Feb 15.

2. Meguro M, Meguro K, Caramelli P, Ishizaki J, Ambo H, Chubaci RYS, Hamada GS, Nitrini R, Yamadori A. Elderly Japanese emigrants to Brazil before World War II: Clinical profiles based on specific historical background. International Journal of Geriatric Psychiatry 2001; 16 : 768-74.

3. Citizenship \& Immigration Canada. Canada's recent immigrants: A comparative portrait based on the 1996 census. Ottawa: Minister of Public Works and Government Services Canada; 2001.

4. Citizenship \& Immigration Canada. Recent immigrants in the Toronto Metropolitan Area: A comparative portrait based on the 1996 census. Ottawa: Minister of Public Works and Government Services Canada; 2000.

5. Canadian Council on Social Development. (2001). [cited 2001 January 12]. Immigrant youth in Canada. [On-line]. Available URL: http:// www.ccsd.ca/subsites/cd/docs/iy/.

6. Joubart N, Raeburn J. Mental Health Promotion: people, power, and passions. International Journal of Mental Health Promotion 1998 Sept: (Inaugural Issue); 15-22.
7. Willinsky C, Pape B. Mental Health Promotion. Social Action Series. Toronto: CMHA National Office; 1997.

8. Lamb S. Everything nice, and not. Readings: A Journal of Reviews and Commentary in Mental Health 1999;14(2):4-9.

9. Rhich GJ. The positive psychology of youth and adolescence. Journal of Youth and Adolescence 2003;32(1):1-3.

10. Magyary D. Positive mental health: A turn of the century perspective. Issues in Mental Health Nursing 2002;23:331-49.

11. Khanlou N, Beiser M, Cole E, Freire M, Hyman I, Kilbride K. Mental health promotion among newcomer female youth: Post-migration experiences and self-esteem/ Promotion de la santé mentale des jeunes immigrantes: Expériences et estime de soi post-migratoires. Ottawa: Status of Women Canada. 2002 (English and French versions).

12. Khanlou N, Hajdukowski-Ahmed M. Adolescent self-concept and mental health promotion in a cross-cultural context. In: Denton $\mathrm{M}$, Hajdukowski-Ahmed M, O'Connor M, Zeytinogly I, editors. Women's voices in health promotion. Toronto: Canadian Scholars' Press; 1999. p.138-151.

13. Khanlou N. Mental health promotion education in multicultural settings. Nurse Education Today 2003;23(2):96-103.

14. Guruge S, Khanlou N. Intersectionalities of influence: Researching health of immigrant and refugee women. 2004. (Submitted).

Data de Recebimento: 28/02/2004

Data de Aprovação: 30/04/2004 